\title{
A STUDY ON STUDENT SUPPORT SERVICES OF IGNOU REGIONAL CENTRE JAIPUR DURING PANDEMIC
}

\author{
Kuldeep Sharma ${ }^{1}$ and Indu Ravi ${ }^{2}$ \\ ${ }^{1}$ IGNOU Regional Centre, Jaipur \\ ${ }^{2}$ Assistant Regional Director, Indira Gandhi National Open University (IGNOU), \\ Regional Centre, Jaipur, Rajasthan, India \\ Email: induravi@ignou.ac.in
}

How to cite this paper:

Sharma, Kuldeep and Ravi, Indu (2021) A Study on Student Support Services of IGNOU Regional Centre Jaipur During Pandemic, Journal of Global Resources, Vol. 07 (02)

DOI:

10.46587/JGR.2021.v07i02.012

Received: 28 March 2021

Reviewed: 25 April 2021

Revised: 17 May 2021

Final Accepted: 25 May 2021

\begin{abstract}
The present study is focused on the importance of Open Distance Learning and Student Support Services provided to the learners during Covid-19 Pandemic. The study emphasizes on the Online Technology Mediated Services provided to learners to facilitate their learning when regular mode of education is on hold. The purpose of this paper is to analyse the changes in the pedagogical shift from traditional methods to new approaches adapting online teaching learning process and student support services during lockdown. The first phase of national wide lockdown in India began from 25 $5^{\text {th }}$ March, 2020 which continued and is not completely open till date. A number of Online Support Services is provided by IGNOU from admissions to result declaration for facilitating the learners. The finding of the present study indicate that 93 percent learners are satisfied with the Online Student Support Services provided by Regional Centre Jaipur during Covid-19 pandemic.
\end{abstract}

Keywords: IGNOU, ODL, Student Support Services, Pandemic

OPEN O A C CES S

Freely available Online www.isdesr.org 


\section{Introduction}

The Indira Gandhi National Open University (IGNOU) established by an Act of Parliament in 1985 is continuously striving to offer quality programmes through Open and Distance Learning (ODL) mode of education. The University has attained major milestones in the history of Open and Distance Learning system and majority of the population in India and abroad gained higher education through IGNOU. Among the world population records, India is second highest populated country and the present formal higher educational institutions are quite not adequate to meet the educational demands of the society. IGNOU as a pioneering leader in ODL has tried to increase the Gross Enrolment Ratio (GER) in the country through its innovative quality programmes. During Covid-19 pandemic the whole education system from school to higher education collapsed not only in India but all over the world. On 11 th March, 2020 the World Health Organization declared COVID-19 a global pandemic. Due to social containment not much information on best practices was available to guide such abrupt transitions in higher education. The goal was to identify student academic challenges and the benefits of distance learning and to use that information for the benefit of students.

IGNOU offers about 228 certificate, diploma, degree and doctoral programmes with strength of nearly 810 faculty members and 574 academic staff at the headquarters and Regional Centres and about 60,000 academic counsellors from conventional institutions of higher learning, professional organizations and industry among others. IGNOU Regional Centre Jaipur covers 20 districts of Rajasthan (Jaipur, Dausa, Tonk, Alwar, Karauli, Dholpur, Bharatpur, Ajmer, Bhilwara, Chittorgarh, Sikar, Jhunjhunu, Hanumangarh, Churu, Sriganganagar, Bundi, Kota, Baran and Jhalawar) offering variety of programmes at different levels (Masters, Bachelors, PG Diplomas, PG Certificates, Diplomas, Certificates and Awareness) related to all disciplines. There are a total 57 Learner Support Centres under Regional Centre Jaipur which includes 27 Regular Centres, 14 Programme Study Centres, 04 Special Study Centres and 13 Jail Centres. IGNOU is providing free education to all the Jail Inmates. A large number of SC/ ST students have been admitted to various programmes of the University and the Fee exemption scheme is being offered from Ministry of Education, Govt. of India. Distance learning programmes of IGNOU are popular nowadays specially after the pandemic situation across the world. The Enrolment in different IGNOU programme offered at Regional Centre, Jaipur shows an increasing trend over the last five years (Fig. 01).

\section{Student Support Services}

Student support service is one of the key areas on which the success of any Open and Distance Learning system depends. As far as IGNOU is concerned, the Regional Centres are entrusted with the key task of providing various kinds of support services. IGNOU in general follows a multimedia approach for instruction using print media (soft copy also available on eGyankosh) and web-based services. The learners are facilitated through the website of IGNOU to ascertain the current status related to their admission, re-registration, material dispatch, address change, results etc. They are also provided online support for filling-up of the examination form, assignments and study material related queries etc. for quick disposal of their grievances without any additional cost. In the Open and Distance Learning mode, the learner enjoys the privilege of self-learning at his/ her own pace and most of them are adult learners who need frequent support from the host institution at different stages of their learning. The following services are offered to learners:

- Induction Meetings at Learner Support Centers

- Self-Instructional Materials (SIM)

- Counselling Session on weekends (Saturday \& Sunday) at Learner Support Centers 
- Library/ Audio-Video/ Teleconferencing/ Radio Counselling

- Maximum duration facility to complete the Programme

- Change of Programme/ Course/ Regional Centre/ Study Centre

- Exam anywhere in India at IGNOU Exam Centers

- Distribution of Study Material to learners

- Online Admission

- Online Re-registration

- Guidance for Early Declaration of Result Facility

- Guidance for Re-Evaluation Facility

- Guidance for Improvement of percentage / Division Facility

- Guidance for Credit Transfer/ Exemption Facility

- Issue of Duplicate Identity Card

- Guidance for Issue of Duplicate Grade Card

- Guidance for Issue of Duplicate Degree

- Issue of Migration Certificate

- Conduct of IGNOU Convocation every year

- Student Grievance Redressal Camps

Every Study Centre has a head, designated as Co-ordinator, who coordinates different activities at the Study Centre. Irrespective of the type of Study Centre, the following six major functions take place at a Study Centre:

- Counseling: Face-to-face counseling for the programmes are provided at the Study centers.

- Project and Practical: Practical are conducted at Study Centers. Guide/ Supervisors for project work are allotted at Study centers.

- Evaluation of Assignments: Tutor Marked Assignments (TMA) are evaluated by the academic counselors empaneled for different courses at the Study Centre. These assignments are returned to the student with tutor's comments and marks obtained. The comments help the student in their studies.

- Audio-Video Facilities: The Study Centers are equipped with audio-video facilities to help the student make use of the audio and video cassettes prepared for different courses. Media notes of these audio-video programmes are also available at the study Centre. This helps the students to know the contents of each programme.

- Library: For each course some of the books suggested under 'Some Useful Books' are available in the Study Centre Library. Audio and video tapes are also available in the library.

- Information and Advice: At the Study Centre the students get relevant information regarding the programmes offered by the University, counseling schedules, examination schedule etc. The student also gets guidance in choosing elective and application-oriented courses.

\section{Objectives of the Study}

The present study has been attempted to obtain the feedback and suggestions of distance learners on the support services rendered by IGNOU Regional Centre, Jaipur during Covid19 pandemic with the following objectives:

1. Study on the growth of LSCs and enrollment trend under IGNOU Regional Centre, Jaipur for the last five years.

2. Analysis of existing practices of Student Support Services at Study centers under IGNOU Regional Centre, Jaipur.

3. To identify the learner's response towards Student Support Services provided by IGNOU Regional Centre, Jaipur by conducting online questionnaire through Google form.

4. Analysis of the support services provided to learners. 


\section{Literature Review}

An effective student-support service is an important pre-requisite for the success of any educational intervention and IGNOU as a premier institution of Open and Distance Learning in the country has developed several mechanisms in this regard to make the learning process much easier. An open learning system is one in which the restrictions placed on students are under constant review and incorporates the widest range of teaching strategies, using independent and individualized learning (Coffey, 1977). According to Kishore (1998), the success or the failure of the Open and Distance Learning system and overall corporate image of an ODL institution are contingent on the strengths and weaknesses of the student support services sub-system.

Student support in Open and Distance Learning has been a fundamental question to address since Open and Distance Learning system has existed. Despite the transformation of Open and Distance Learning into a technology-based system, the principles of support services for distance learners remain the same, in which students are engaged in learning and motivated to learn independently and autonomously. Recent research highlights the importance of academic and non-academic support and the roles of technologies to enable the development of more flexible, interactive and personalized learning environments that require new ways of providing learning support for open distance and online students (Sánchez-Elvira Paniagua and Simpson, 2018).

Simpson (2000) identified two major areas of learner support i.e., academic and administrative support services are very much important for the success of the Open and Distance Learning system. Further, he defined that academic support as the incorporation of a variety of functions such as explaining concepts, providing hands on practical experience, developing learning skills etc. Student satisfaction in distance education has been examined by a number of researchers (Hilgenberg \& Tolone, 2000; Jones, 1992; McCleary \& Egan, 1989). One of the most common problems of many distance learning courses is the limitation of dialogue between teachers and learners, and amongst learners themselves. Tait (1997) has pointed out that modern ODL institutions have been practicing many elements of quality control and assurance system with a motto to rule out bad practices. The measures to strengthen quality control and quality assurance should be focused to improve the system. During Covid-19 pandemic teachers and students both find themselves in the situation where they felt compelled to embrace the digital academic experience of the online teaching-learning process (Lederman, 2020). Mishra et al. (2020) analyzed online teaching learning in higher education during lockdown due to Covid-19 and they concluded that acquaintance with online teaching learning is essential for both teachers and students for future education.

Every distance education learner needs awareness about Open and Distance Learning system and the functioning of the University and thus IGNOU conducts induction meeting at the beginning of every academic session for its learners at the study center level. Hence, from the overall perspective the role of Regional Centre in IGNOU system is very much crucial in maintaining smooth relationship with the study centers and abiding the rules and execution of work entrusted by the Headquarters from time to time. The present study has attempted to analyze the importance of student support services at IGNOU Regional Centre, Jaipur to ascertain the perception of learners to pave way to find nuances in the services for effective implementation of student support services for student satisfaction. 


\section{Methodology}

Both Quantitative and Qualitative methodology were used to study the changes in the student support services provided to the learners during Covid-19 pandemic. The study is delimited to the support services provided to the learners of Regional Centre, Jaipur.

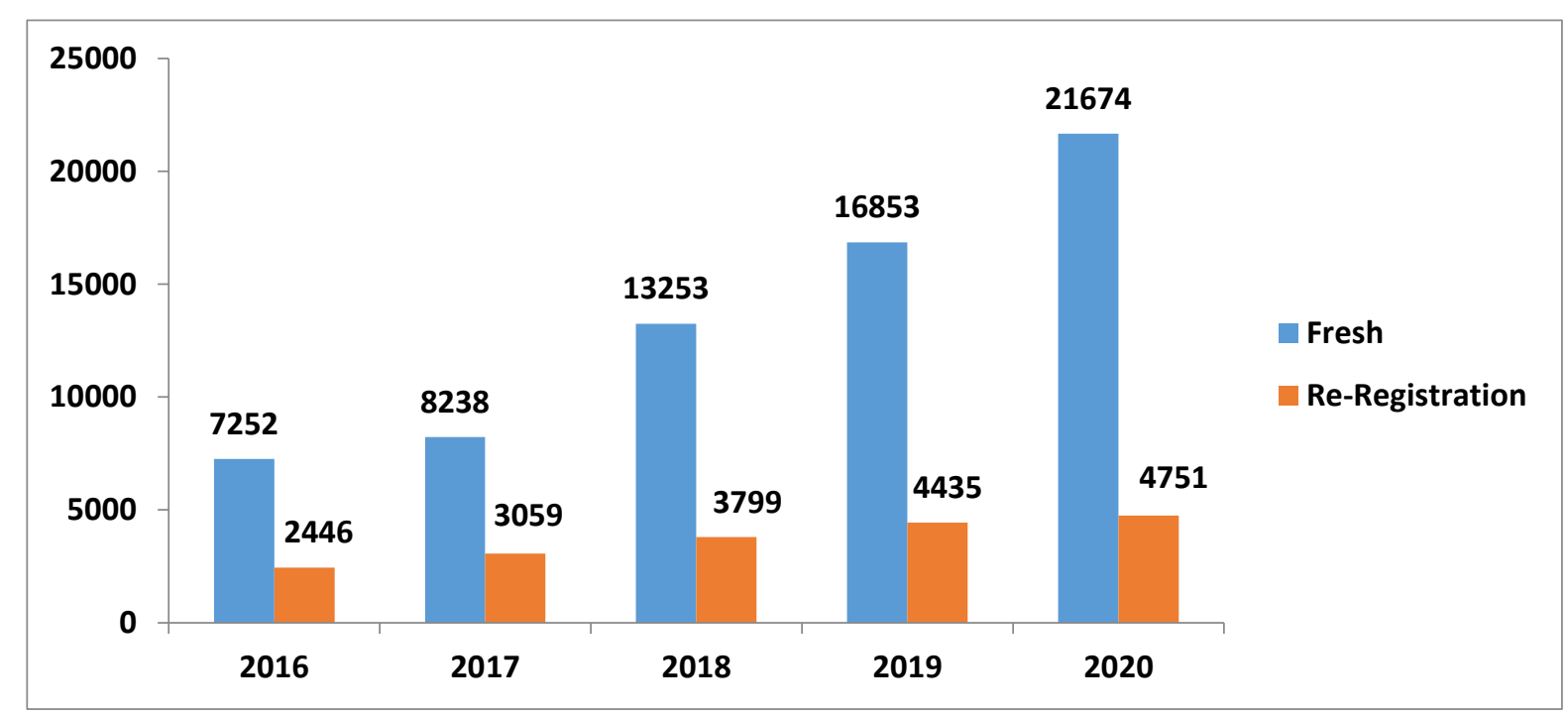

Figure 01: Enrolment Trend for The Last Five Years Under Regional Centre Jaipur

\section{Population/Sample and Data Collection}

200 Learners were randomly taken as a sample to survey their perception towards student support services provided to them by the Regional Centre/ Learners Support Centres. For this a Google Form was developed and sent to the Masters/ Bachelors Programme Learners to submit the responses within a stipulated time period. About 150 Learners including learners in rural and urban areas responded to the questionnaire and the feedback of the learners was collected in Excel Work Sheet for data analysis.

\section{Findings and Discussions}

Student support service is the crux of the Open and Distance Learning System as most of the learners are adult in nature and employed. They seek routine help from the ODL institution for timely completion of the study and to avoid subject related fears and depression. Even though the study centres arrange Academic Counselling on weekends and holidays, there is always need for communication to students about the schedules and timings for prior preparations at their end. The IGNOU Regional Centre, Jaipur provides all types of student support services to its learners and conducts routine monitoring of Learner Support Centres for the conduct of counselling sessions, ICT engagement, Multimedia lesson facilities, library facilities, assignment evaluation, conduct of practical sessions and guidance on projects. Since IGNOU conducts Term End Examinations twice a year viz. June and December, the academics at Regional Centre routinely visit the examination centres for effective conduct of the examinations. IGNOU in the recent years has made several online facilities like Online Admission, SLM delivery information, e-Gyankosh web repository for all SLMs, Assignment Download, Library Facilities, i-Gram portal for Student grievances redressal mechanism, ReRegistration, Term End Examination form for the Learners and with the help of smart phones could be able to seek all the study related information anywhere and anytime basis. 
Table 01: Student Support Services provided by Regional Centre Jaipur during Covid19 pandemic

\begin{tabular}{|c|c|c|c|}
\hline \multirow[t]{2}{*}{ S.N. } & \multirow[t]{2}{*}{ Parameters } & \multicolumn{2}{|c|}{ Responses - Total 150 out of 200} \\
\hline & & Satisfactory & Not Satisfactory \\
\hline 1. & Online Pre-admission Counselling & $\begin{array}{c}142 \\
(94.66 \%)\end{array}$ & $\begin{array}{c}08 \\
(05.33 \%)\end{array}$ \\
\hline 2. & Online/Admission process at Regional Centre & $\begin{array}{c}142 \\
(94.66 \%)\end{array}$ & $\begin{array}{c}08 \\
(05.33 \%)\end{array}$ \\
\hline 3. & $\begin{array}{l}\text { Issue of guidelines and Student ID card through } \\
\text { Online mode }\end{array}$ & $\begin{array}{c}141 \\
(93.99 \%)\end{array}$ & $\begin{array}{c}09 \\
(06.01 \%)\end{array}$ \\
\hline 4. & Study Material Delivery Mechanism & $\begin{array}{c}140 \\
(93.33 \%)\end{array}$ & $\begin{array}{c}10 \\
(06.67 \%)\end{array}$ \\
\hline 5. & $\begin{array}{l}\text { Receipt of Counselling Schedule timely through } \\
\text { Online mode }\end{array}$ & $\begin{array}{c}134 \\
(89.33 \%)\end{array}$ & $\begin{array}{c}16 \\
(10.67 \%)\end{array}$ \\
\hline 6. & $\begin{array}{l}\text { Quality of the Academic Counsellor through } \\
\text { Online mode }\end{array}$ & $\begin{array}{c}144 \\
(95.99 \%)\end{array}$ & $\begin{array}{c}06 \\
(04.01 \%)\end{array}$ \\
\hline 7. & $\begin{array}{l}\text { Usefulness of Academic Counselling through } \\
\text { Online mode }\end{array}$ & $\begin{array}{c}143 \\
(95.32 \%)\end{array}$ & $\begin{array}{c}07 \\
(04.68 \%)\end{array}$ \\
\hline 8. & $\begin{array}{l}\text { Guidance in Writing Assignments, Projects, } \\
\text { Practical, Internship, Workshops through Online } \\
\text { mode }\end{array}$ & $\begin{array}{c}142 \\
(94.66 \%)\end{array}$ & $\begin{array}{c}08 \\
(05.34 \%)\end{array}$ \\
\hline 9. & $\begin{array}{l}\text { Responding of queries by Regional Centre } \\
\text { submitted by learners through Online Mode i- } \\
\text { Gram, Email, Quick Contact, Telephonically, } \\
\text { Letters etc. }\end{array}$ & $\begin{array}{c}142 \\
(95.66 \%)\end{array}$ & $\begin{array}{c}08 \\
(04.34 \%)\end{array}$ \\
\hline 10. & $\begin{array}{l}\text { Receiving of SMS alerts, Emails, Telephones } \\
\text { calls timely regarding submission of } \\
\text { Assignments, Term End Examination, Re- } \\
\text { registration, Online Admission and other IGNOU } \\
\text { activities }\end{array}$ & $\begin{array}{c}140 \\
(93.33 \%)\end{array}$ & $\begin{array}{c}10 \\
(06.67 \%)\end{array}$ \\
\hline 11. & $\begin{array}{l}\text { Guidance for filling Term End Examination Form } \\
\text { through Online mode }\end{array}$ & $\begin{array}{c}136 \\
(90.66 \%)\end{array}$ & $\begin{array}{c}14 \\
(09.34 \%)\end{array}$ \\
\hline 12. & $\begin{array}{l}\text { All type of Online Web Based Support Services } \\
\text { rendered by Regional Centre }\end{array}$ & $\begin{array}{c}137 \\
(91.33 \%)\end{array}$ & $\begin{array}{c}13 \\
(08.67 \%)\end{array}$ \\
\hline 13. & $\begin{array}{l}\text { Online Student Grievance Redressal } \\
\text { Mechanism }\end{array}$ & $\begin{array}{c}139 \\
(92.66 \%)\end{array}$ & $\begin{array}{c}11 \\
(07.34 \%)\end{array}$ \\
\hline 14. & $\begin{array}{l}\text { All type of Academic and Administrative Support } \\
\text { Services rendered by Regional Centre through } \\
\text { Online mode }\end{array}$ & $\begin{array}{c}140 \\
(93.33 \%)\end{array}$ & $\begin{array}{c}10 \\
(06.67 \%)\end{array}$ \\
\hline 15. & $\begin{array}{l}\text { All type of Academic and Administrative Support } \\
\text { Services rendered by Learner Support centers } \\
\text { through Online mode }\end{array}$ & $\begin{array}{c}141 \\
(94.00 \%)\end{array}$ & $\begin{array}{c}09 \\
(06.00 \%)\end{array}$ \\
\hline & $\begin{array}{l}\text { Overall perspective on Student Support } \\
\text { Services through Online mode }\end{array}$ & $\begin{array}{c}141 \\
(95.00 \%)\end{array}$ & $\begin{array}{c}09 \\
(06.00 \%)\end{array}$ \\
\hline & $\begin{array}{l}\text { erage in Number and } \\
\text { Percentage }\end{array}$ & $\begin{array}{c}139 \\
(92.74 \%)\end{array}$ & $\begin{array}{c}11 \\
(07.26 \%)\end{array}$ \\
\hline
\end{tabular}

The enrolment status of IGNOU Regional Centre, Jaipur shows an increasing trend in the admissions cycles over the last five years (Fig. 01). IGNOU has been following online admission procedure since the last two years. The Enrolment status for July 2020 session during pandemic had 13099 admissions. During the Covid-19 pandemic situation across the country IGNOU Regional Centre, Jaipur developed online mechanism for submission of Assignments which greatly helped the learners to submit their assignments online in soft copy rather than to go to submit the hard copy at allotted Study Centres or Regional Centre. IGNOU Regional Centre, Jaipur extended all possible online support to learners during Covid-19 pandemic which are listed below:

- Online Submission of Assignments in soft copy through Google Link and upload guidelines on 
Home page of Regional Centre, Jaipur for wider dissemination and information of learners http://rcjaipur.ignou.ac.in/news/detail/1/Submission_of_Scan_Copy_of_Hand_Written_Assign ment_Link-162

- Links for downloading soft copy of study material

http://rcjaipur.ignou.ac.in/news/detail/1/Digital_study_materials_available_on_IGNOU_websit e_e_Gyankosh_-159

- Link for downloading study material from e-Gyankosh for BA General, Honours, BCOM, BSCG and BAVTM http://rcjaipur.ignou.ac.in/news/detail/1/ website

- Guidelines for Online Submission of Project synopsis, projects of various IGNOU programmes.

- Uploading of all information, circulars, announcements on Home page of Regional Centre, Jaipur as well as on Facebook, Twitter http://rcjaipur.ignou.ac.in/news/1

- Online Counseling Schedule uploaded on home page of Regional Centre, Jaipur for information of learners.

- Online Counseling sessions conducted at various Learners Support Centers under Regional Centre, Jaipur from subject experts using Webex, Cisco, Zoom App, Google Meet Online platforms.

- Responding of learner's queries received through Emails, i-Gram, during Counseling sessions, telephonically.

- Uploading monthly Interactive Radio Counseling schedule on Regional Centre, Jaipur website as well as regular updates about Counseling sessions organized by HQs on social medial platform of Regional Centre, Jaipur like Facebook, Twitter etc.

- IGNOU Gyanvani FM Radio Channel 105.6 MHz plays an important role during Covid-19 pandemic situation to deliver information to the learners within $100 \mathrm{Km}$ range.

- SMS alerts, Emails are also forwarded to learners on Email ID about latest IGNOU activities, announcements, circulars, information about last dates, guidelines for newly enrolled learners for timely submission of assignments, projects, project synopsis, re-registration form, revaluation form, internships, term end examination form etc.

- Schedule of IGNOU online counseling offered by Faculty of different schools of IGNOU of various disciplines through Gyandhara channel uploaded on Regional Centre, Jaipur website.

- Extensive use of Social Media platforms like Facebook, Twitter, Whatsapp etc. to provide instant information to the learners.

The finding of the present study for student satisfaction related to student support services provided by Study Centre and Regional Centre during pandemic were received from 150 learners out of 200 (Table 01). From the table it is inferred that 75 percent learners responded to the 16 parameters of the questionnaire. The parameters like Online preadmission counselling, Online Admission process and handling, Online Issue of guidelines and ID card, SLM, information from LSC on counselling schedule, assignment submission, practical counselling, guidance, web related information on various issues and overall student support services gains nearly 93 percent satisfactory levels from the learners of Regional Centre, Jaipur. 7.26 percent learners were not satisfied with the Online Student Support services provided. The reason for this was analysed and found to be that most of these learners were from rural areas where internet facilities are not proper. Most of them were not familiar with the use of online platforms used initially for counseling sessions. Print study material was not available to them during the initial lockdown phase which caused inconvenience to many of them who could not study from the downloaded material available on IGNOU website. The remaining 92.74 percent learners were satisfied with online student support services provided. Most of these learners were from urban areas and possessed proficient computer literacy. Further, it was observed during virtual classroom experience that proper online etiquettes need to be followed by the learners about which many of them were 
unaware. After almost a year since the pandemic was declared we can now say that distance digital learning is the new normal and requires a learning process for both stakeholders and we need to accept the change in the pedagogical process. The findings inferred from the Online questionnaire on student support services during Covid-19 pandemic suggested that the Regional Centre need to proactively work on solving grievances on student related issues and timely extend support to the learners in all the sphere of academic activities from admission to results declaration more efficiently and effectively to improve the image of IGNOU among general public.

\section{Conclusion}

The students as well as Academic Counselors involved in distance learning will need to adjust with the online mode of education and changes that have occurred in the pedagogical process during the last one year. Everyone has to live with the present crises and it may continue in future. Learners need to be more computer friendly and literate. The Government should think of providing high speed internet facilities even in remote rural areas. The learners today have smart phones where knowledge is available at their fingertips. IGNOU Regional Centre, Jaipur extended to provide all possible student support services during the pandemic situation due to Covid-19 for smooth completion of their programme using technology mediated web enabled ICT services. The students of regular colleges and Universities nowadays are increasingly aspiring to take IGNOU ODL programmes as ADD ON courses to simultaneously pursue during their regular study since the job markets in India are expecting multifarious skills. There has to be excessive use of technology mediated services for providing student support services to learners especially in marginalized and disadvantaged segment of the society. We also require to promote distance learning as the future in education as of now is of online teaching learning.

\section{References}

1. Coffey, J. (1977). Open learning opportunities for mature students. In Davies, T.C. (Ed.), Working Paper 14: Open Learning Systems for Mature Students. London: Council for Educational Technology.

2. Hilgenberg, C. \& Tolone, W. (2000). Student perceptions of satisfaction and opportunities for critical thinking in distance education by interactive video, The American Journal of Distance Education, 14(3), 59-73.

3. Jones, T. (1992). IITS students' evaluation questionnaires for the fall semester of 1991. A summary and report. (ERIC document Reproduction Service No. ED 345716) Journal of Open Learning, 7(2), 205-212

4. Kishore, S. (1998). Student Support and Quality Indicators in Distance Learning. Indian Journal of Open Learning, 7(2), 205-12.

5. Lederman, D. (2020)) (March 18, Will shift to remote teaching be boon or bane for inline learning? Inside Higher Ed. Retrieved from file:///D:/COVID/ Most\% 20teaching\%20is\%20going\%20remote.\%20Will\%20that\%20help\%20or\%20hurt\%20onli ne\%20learning.html.

6. McCleary, I. D., \& Egan, M. W. (1989). Program design and evaluation: Two-way interactive television. The American Journal of Distance Education, 3(1), 50-60.

7. Mishra L, Gupta T \& Shree Abha (2020). Online teaching- learning in higher education during lockdown period of Covid-19 pandemic.

8. Sánchez-Elvira Paniagua, A. and Simpson, O. (2018), "Developing student support for open and distance learning: the EMPOWER project", Journal of Interactive Media in Education, Vol. 1 No. 9, pp. 1-10, available at: https://doi.org/10.5334/jime.

9. Simpson, Ormond (2000). Supporting Students in Open and Distance Learning. Publisher Kogan page. ISBN 9780203417003

10. Tait, A. (1997). Quality Assurance In Higher Education: Selected Case Studies. Vancouver, BC The Commonwealth of Learning. 